\title{
Hard coal and international seaborne trade
}

ABSTRACT: A significant part of hard coal production (15-19\% in the years 2010-2017, i.e. 1.0-1.3 billion tons per year) is traded on the international market. The majority of coal trade takes place by sea, accounting for $91-94 \%$ of the total coal trade. The article discusses the share of coal in international seaborne trade and the largest coal ports. Coal is one the five major bulk commodities (in addition to iron ore, grain, bauxite, alumina, and phosphate rock). In the years 2010-2016, the share of coal in international seaborne trade and major bulk commodities was $36-41 \%$ and $11-12 \%$, respectively. Based on the analysis of coal throughput in different ports worldwide, the ports with the largest throughput include the ports of Qinhuangdao (China), Newcastle (Australia), and Richards Bay (South Africa). For 2013-2017, their throughput amounted to a total of 411-476 million tons of coal. The largest coal exporting countries were: Australia, Indonesia, Russia, Colombia, South Africa, and the US (a total of $85 \%$ share in global coal exports), while the largest importers are Asian countries: China, India, Japan, South Korea and Taiwan (a $64 \%$ share in global imports). In Europe, Germany is the largest importer of coal (54 million tons imported in 2016). The article also discusses the freight costs and the bulk carrier fleet. Taking the price of coal at the recipient's (i.e. at the importer's port) into account, the share of freight costs in the CIF price of steam coal (the price of a good delivered at the frontier of the importing country) was at the level of $10-14 \%$. In the years 2010-2016, the share of bulk carriers in the world fleet was in the range of $11-15 \%$. In terms of tonnage, bulk carriers accounted for $31-35 \%$ of the total tonnage of all types of ships in the world. The share of new (1-4 years) bulk carriers in the total number of ships on a global scale in the years 2010-2016 was $29-46 \%$.

KEYWORDS: hard coal, seaborne trade, sea ports, throughput, freight costs

\footnotetext{
${ }^{1}$ Mineral and Energy Economy Research Institute of the Polish Academy of Sciences, Kraków, Poland; e-mail: kszlugaj@min-pan.krakow.pl; zg@min-pan.krakow.pl
} 


\section{Introduction}

In the years 2010-2017, hard coal traded in the international market accounted for about 15$19 \%$ (1.0-1.3 billion tons/year) of the world production of this raw material. The largest world coal sales were recorded in 2012-2013; they amounted to approximately 1.3 billion tons (Fig. 1).

The large part of coal trade takes place by sea (Fig. 1). In 2010-2017, the coal seaborne trade was at the level of 1.0-1.2 million tons per year, which accounted for as much as $91-94 \%$ of the total trade of this raw material. It should be noted that steam coal has the largest share (74-77\% or $0.71-0.82$ billion tons) in the coal seaborne trade (Fig. 2).

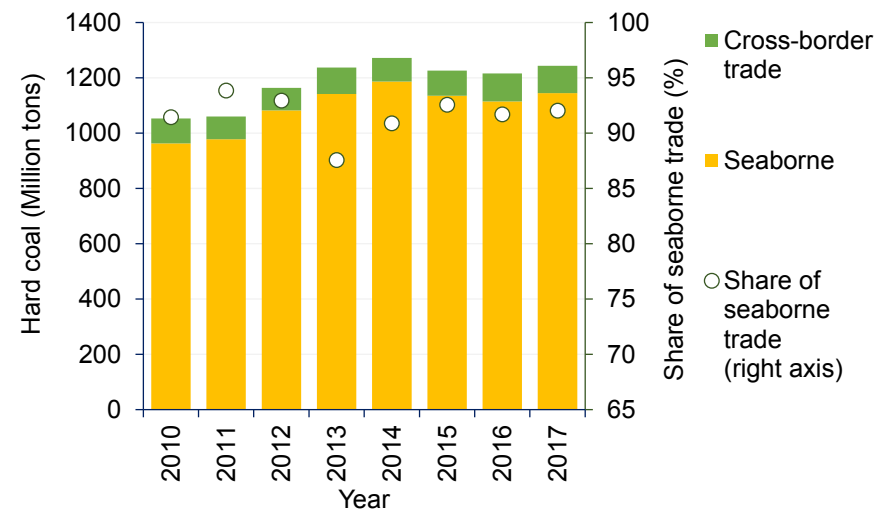

Fig. 1. The international hard coal market by trade routes, 2010-2017 Source: own work based on VDKI (2011-2018)

Rys. 1. Międzynarodowy rynek węgla kamiennego według dróg handlowych, lata 2010-2017

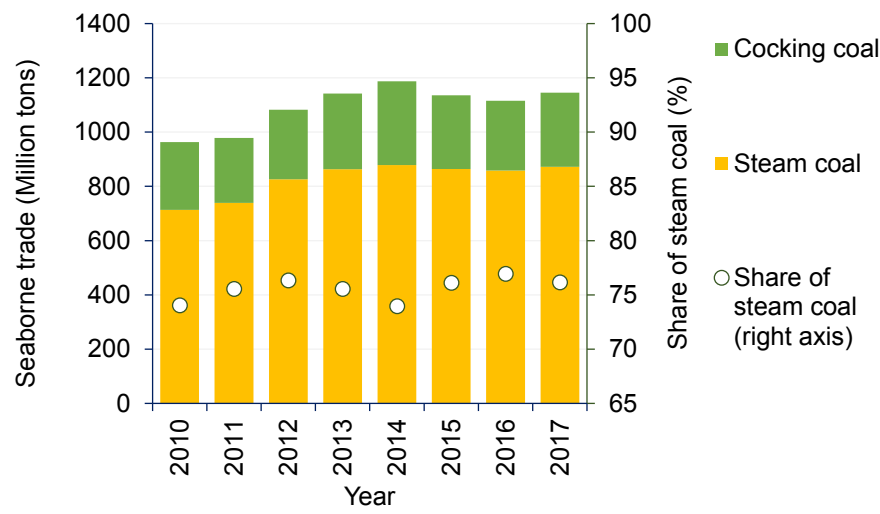

Fig. 2. The international seaborne trade of steam coal and coking coal in the years 2010-2017 Source: own work based on VDKI (2011-2018)

Rys. 2. Światowe obroty węgla energetycznego i koksowego w handlu morskim, lata 2010-2017 
Due To the fact that the international seaborne trade of coal takes place by sea, the main aim of the article is to analyze the share of coal and the largest coal ports in the international seaborne trade, and the share of freight costs in in the price of a good delivered at the frontier of the importing country. To eliminate differences in the methodology of aggregating statistics related to the production, export, import, and trade in hard coal, the same source of data was used.

\section{International seaborne trade by cargo groups and the largest ports in the world}

The world seaborne trade is constantly evolving: in 1980, the total cargo volume amounted to less than 4 billion tons, while in 2015 it exceeded 10 billion tons (Fig. 3). The increase in international trade, and especially the growing share of sales of finished products, contributed to a change in the structure of cargo. In 1980, the largest group was the transport of crude oil and gas with a share at the level of $51 \%$, while from 2012 on this share has dropped to $30-31 \%$. The biggest development can be observed in the case of bulk carriers, whose share in the world seaborne trade has increased from 3 to $17 \%$.

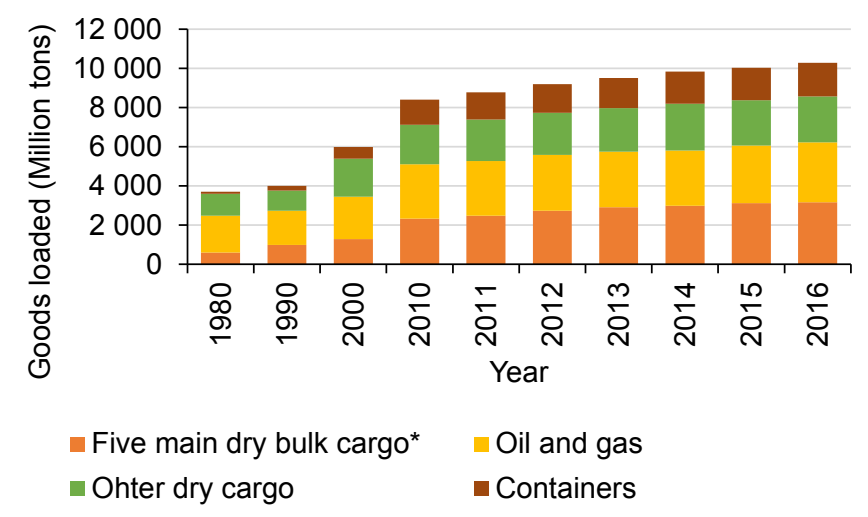

Fig. 3. The international seaborne trade by cargo groups Source: own work based on UNCTAD/RMT (2011-2017)

* Five main dry bulk cargo: iron ore (1), grain (2), coal (3), bauxite, alumina (4), and phosphate rock (5)

Rys. 3. Międzynarodowe obroty ładunkowe w handlu morskim według grup ładunków

Coal (in addition to iron ore, grain, bauxite, alumina, and phosphate rock) is one the so-called five major dry bulk commodities. In recent years, the share of coal in international seaborne trade (Fig. 4) and major bulk commodities was 36-41\% (2010-2016) and 11-12\%, respectively. The 
data for the chart was taken from reports published by the United Nations Conference of Trade and Development on maritime transport (UNCTAD/RMT 2011-2017). Compared to statistics presented by (VDKI 2011-2018), the data related to maritime coal trade are lower by about 76-149 million tons.

For the first time in thirty years, a decrease in coal seaborne trade was recorded in 2015 (UNCTAD/RMT 2011-2017). In annual terms, transport decreased by 6\%, dropping by 70 million tons. The situation in China, where the growth rate has dropped, import restrictions regarding low quality coal, and the introduction of emission limits have a significant impact on the volume of coal transport.

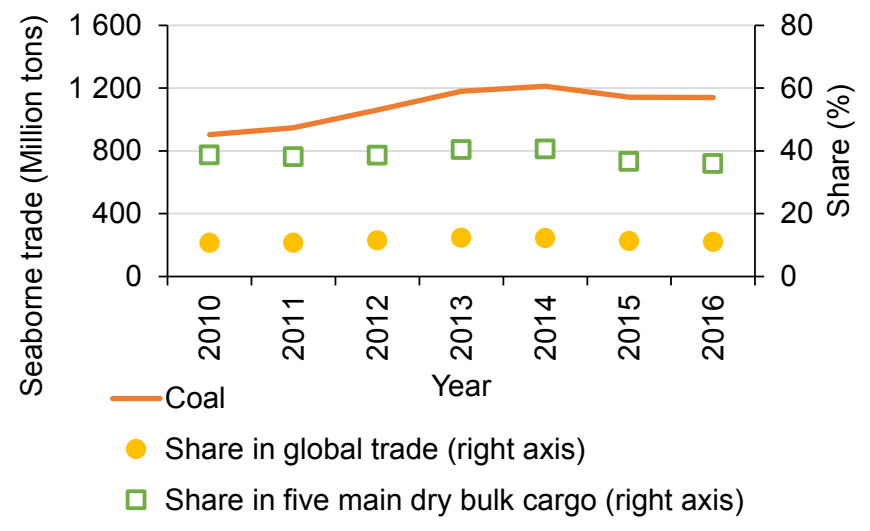

Fig. 4. The international seaborne trade of coal Source: own work based on UNCTAD/RMT (2011-2017)

Rys. 4. Międzynarodowe obroty ładunkowe węgla w handlu morskim

Numerous rankings of the world's leading seaports can be found on industry portals and in numerous magazines related to maritime affairs. The ranking of the largest ports in the world (Table 1) was based on the ranking developed by the Port of Rotterdam Authority (Rotterdam Port... 2011-2017). Due to the fact that the latest publications of the port no longer present data on the so-called The Top 20 World Ports, throughput statistics were supplemented by other data sources presented in the table below.

The economic boom in Asian countries translated into an increase in throughput. Out of twenty of the presented ports, only three are not located in Asia, while fourteen of them are located in China. In 2017, the total cargo throughput of Qinhuangdao Port exceeded one billion tons. This makes the port the first in the world to exceed such volume.

Based on the analysis of throughput of all ports for the years 2017 and 2010, a steady increase in throughput can be observed. In seven cases it was a two-fold increase, while a three-fold increase was recorded in one case. With the exception of the South Korean port of Busan, in six cases they applied to Chinese ports. The exception is the Chinese port of Qinhuangdao, which recorded a 7\% decrease in throughput (by 19 million tons). 
TABLE 1. The ranking of the largest ports in the world [million tons]

TABELA 1. Ranking największych portów świata [mln ton]

\begin{tabular}{|c|c|c|c|c|c|c|c|c|}
\hline \multirow{3}{*}{ Port } & \multirow{3}{*}{ Country } & \multicolumn{4}{|c|}{ Cargo Throughput } & \multicolumn{3}{|c|}{ Rank } \\
\hline & & 2010 & 2015 & 2017 & \multirow{2}{*}{$\begin{array}{c}\text { Growth rate }+/- \\
2017 / 2010 \\
\%\end{array}$} & 2010 & 2015 & 2017 \\
\hline & & \multicolumn{3}{|c|}{ million tons } & & \multicolumn{3}{|c|}{ place } \\
\hline Ningbo-Zhoushan & China & 627 & 889 & 1001 & 60 & 2 & 1 & 1 \\
\hline Shanghai & China & 653 & 717 & 706 & 8 & 1 & 2 & 2 \\
\hline Singapore & Singapore & 503 & 575 & 626 & 24 & 3 & 3 & 3 \\
\hline Suzhou & China & 330 & 540 & 608 & 84 & 8 & 5 & 4 \\
\hline Guangzhou & China & 400 & 520 & 566 & 42 & 6 & 6 & 5 \\
\hline Tangshan & China & 251 & 490 & 565 & 126 & 12 & 8 & 6 \\
\hline Qingdao & China & 350 & 500 & 508 & 45 & 7 & 7 & 7 \\
\hline Port Hedland & Australia & 179 & 453 & 505 & 183 & 17 & 10 & 8 \\
\hline Tianjin & China & 408 & 541 & 503 & 23 & 5 & 4 & 9 \\
\hline Rotterdam & $\begin{array}{l}\text { The Nether- } \\
\text { lands }\end{array}$ & 430 & 466 & 467 & 9 & 4 & 9 & 10 \\
\hline Dalian & China & 301 & 415 & 451 & 50 & 9 & 11 & 11 \\
\hline Busan & South Korea & 241 & 324 & 401 & 66 & 13 & 14 & 12 \\
\hline Yingkou & China & 225 & 339 & 362 & 61 & 14 & 13 & 13 \\
\hline Rizhao & China & 221 & 361 & 360 & 63 & 16 & 12 & 14 \\
\hline South Louisiana & USA & 223 & 266 & 308 & 38 & 15 & 17 & 15 \\
\hline Gwangyang & Korea Rep. & N.A. & 272 & 292 & - & - & 16 & 16 \\
\hline Yantai (Chefoo) & China & 150 & 245 & 287 & 91 & 18 & 20 & 17 \\
\hline Hong Kong & China & 268 & 257 & 282 & 5 & 10 & 18 & 18 \\
\hline Zhangjiagang & China & N.A. & 280 & 282 & - & - & 15 & 19 \\
\hline Qinhuangdao & China & 257 & 253 & 238 & -7 & 11 & 19 & 20 \\
\hline
\end{tabular}

Source: own work based on Rotterdam-Port... (2011-2017); Global ports... 2018, port data.

\section{The major exporters and importers of hard coal in the world}

In order to analyze the largest coal ports, one should first look at the largest exporters and importers of coal.

Fig. 5 presents the six largest producers and importers of coal in the world. The chart shows statistics for the years 2010 and 2016.

The three largest exporters are: Australia, Indonesia, and Russia. The largest importers of coal are: China, India, and Japan. Interestingly, the largest exporters represent all major con- 
tinents. Australia, Eurasia, America, and Africa. On the other hand, importers, except for the European Union, are represented exclusively by Asian countries.

a)

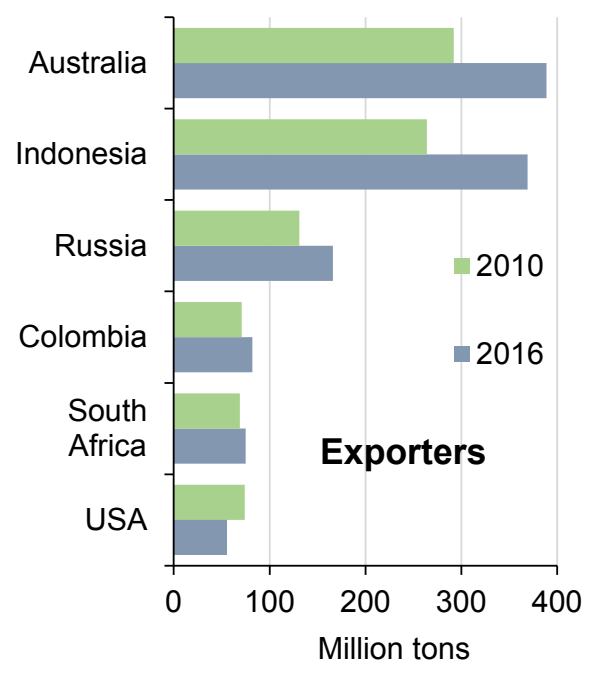

b)

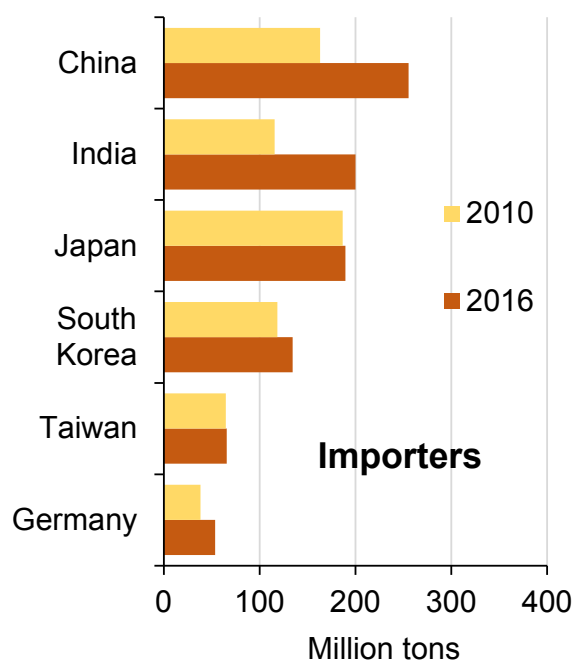

Fig. 5. The comparison of major exporters a) and importers b) of hard coal in the world Source: own work based on Coal Information 2017

Rys. 5. Porównanie czołowych eksporterów i importerów węgla kamiennego na świecie

Table 2 presents the volume of hard coal exports, major exporters of hard coal, and hard coal export structure by continents. The share of OECD countries in coal exports has also been shown. Since 2010, the largest increase was reported for exports from Australia (by 33\%), which gives an average annual growth of 4.9\%. Exports from Indonesia (the largest exporter of thermal coal) increased by $40 \%$ and, in addition, the growth rate in this country was the highest and amounted to $5.7 \%$ per annum. The six largest exporters of hard coal have a $85 \%$ share in the total world exports, which in 2016 amounted to around 1.32 billion tons.

The largest importer of hard coal in 2016, taking the place of Japan, which was the largest exporter of this raw material for many years, was China (Table 3). Compared to 2010, the increase in imports amounted to $56.7 \%$ with an average annual growth rate of $7.8 \%$. However, the highest increase in imports occurred in India: in 2016, the country imported 200 million tons, which is an increase of $72.9 \%$ (with an average increase of $9.6 \%$ per year) compared to the year 2010. The share of the Asian countries listed in Table 3 (representing the top five largest importers) in the global hard coal imports in 2010 amounted to $60 \%$ and increased to $64 \%$ in 2016 . On the other hand, the share of all Asian countries in global hard coal exports in 2016 amounted to $62 \%$ (Fig. 6) and increased by 2 percentage points compared to 2010. 
TABLE 2. The main exporters of hard coal - exports by continents

TABELA 2. Główni eksporterzy węgla kamiennego - struktura kierunków eksportu węgla kamiennego według kontynentów

\begin{tabular}{|c|c|c|c|c|c|c|c|c|}
\hline \multirow[t]{2}{*}{ Exporter } & $\begin{array}{c}\text { Volume } \\
\text { (hard coal) }\end{array}$ & Asia & Europe & $\begin{array}{l}\text { The Ame- } \\
\text { ricas }\end{array}$ & Africa & \multirow[t]{2}{*}{ OECD } & & \\
\hline & Million tons & \multicolumn{4}{|c|}{$\%$} & & & \\
\hline \multicolumn{7}{|c|}{2010} & & \\
\hline Australia & 292 & 89 & 6 & 3 & - & 61 & & \\
\hline Indonesia & 264 & 93 & 5 & 1 & - & 36 & & \\
\hline Russia & 131 & 32 & 63 & - & - & 73 & & \\
\hline Colombia & 71 & 21 & 54 & 24 & - & 76 & & \\
\hline South Africa & 69 & 70 & 15 & 4 & 5 & 33 & & \\
\hline USA & 74 & 30 & 37 & 26 & - & 70 & & \\
\hline \multirow{2}{*}{\multicolumn{7}{|c|}{2016}} & \multicolumn{2}{|c|}{ Change, percentage value } \\
\hline & & & & & & & $2016 / 2010$ & $\begin{array}{l}\text { Annual } \\
\text { average }\end{array}$ \\
\hline Australia & 389 & 89 & 5 & 4 & - & 55 & 33 & 4.9 \\
\hline Indonesia & 369 & 98 & 2 & - & - & 21 & 40 & 5.7 \\
\hline Russia & 166 & 51 & 42 & 1 & - & 64 & 27 & 4.0 \\
\hline Colombia & 82 & 14 & 61 & 18 & - & 85 & 15 & 2.4 \\
\hline South Africa & 75 & 74 & 13 & 2 & 9 & 19 & 9 & 1.4 \\
\hline USA & 55 & 27 & 40 & 28 & - & 68 & -26 & -4.8 \\
\hline
\end{tabular}

Source: own work based on Coal Information 2017.

TABLE 3. The main importers of hard coal in 2010 and 2016

TABELA 3. Główni importerzy węgla kamiennego w 2010 i 2016 roku

\begin{tabular}{|c|c|c|c|c|}
\hline \multirow{2}{*}{ Importer } & 2010 & 2016 & \multicolumn{2}{c|}{ Change, percentage value } \\
\cline { 2 - 5 } & \multicolumn{2}{|c|}{ Million tons } & $2016 / 2010$ & Annual average \\
\hline China & 163 & 256 & 56.7 & 7.8 \\
\hline India & 116 & 200 & 72.9 & 9.6 \\
\hline Japan & 187 & 189 & 1.4 & 0.2 \\
\hline South Korea & 119 & 135 & 13.4 & 2.1 \\
\hline Taiwan & 65 & 66 & 1.1 & 0.2 \\
\hline Germany & 39 & 54 & 39.2 & 5.7 \\
\hline Turkey & 21 & 36 & 70.0 & 9.2 \\
\hline Italy & 22 & 17 & -24.0 & -4.5 \\
\hline World & 1,087 & 1,327 & 22.1 & 3.4 \\
\hline OECD & 435 & 468 & 7.6 & 1.2 \\
\hline
\end{tabular}

Source: own work based on Coal Information 2017. 


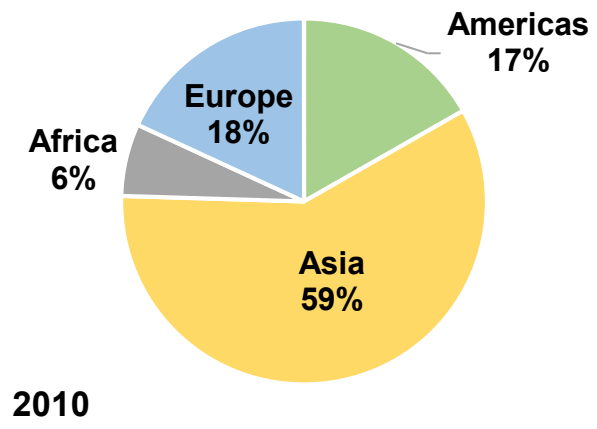

Fig. 6. The world hard coal export by continents in the years 2010 and 2016 Source: own work based on Coal Information 2017

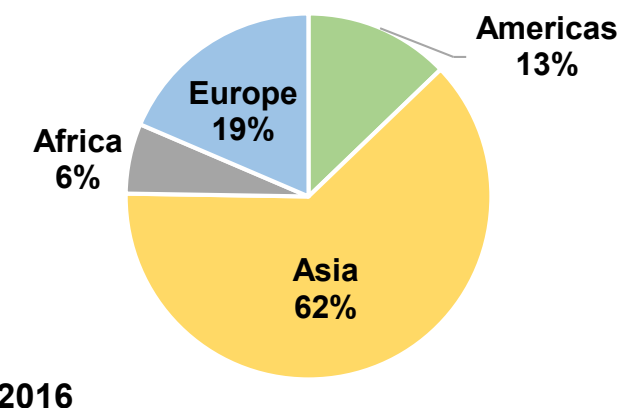

2016

\section{The largest coal hubs in the world}

Coal throughput in the major ports of the world are presented in Fig. 7. The data is ranked in descending order in relation to the coal throughput in 2017. Due to the fact that Amsterdam-Rotterdam-Antwerp (ARA) ports make up the most important hub for maritime activity in Western Europe, these ports are merged in the graph. In addition, the chart shows the total hard coal seaborne trade according to the statistics of the German association of coal importers - Verein der Kohleimporteure E. V. (VDKI 2011-2018).

Taking the ports listed in Fig. 7 into account, coal throughput in the first three ports, namely: Qinhunagdao, Newcastle, and Richards Bay amounted to 411-476 million tons (the years 20132017), which is theoretically $34-38 \%$ of the international coal trade. However, the authors are aware that the volumes presented in Fig. 7 refer to the total coal throughput, i.e. including export, import, and domestic transportation.

The Qinhuangdao port, the world's largest coal port in terms of throughput, acts as the major transiting port, from which coal is supplied mainly to domestic and export markets (Table 4). According to the available data (Qinhuangdao Annual Report 2013-2017) coal throughput in the years $2013-2017$ was in the range from 177 to 246 million tons, accounting for $92-98 \%$ of the total throughput of the port.

When it comes to the volume of coal exports, it is the highest in the Australian port of Newcastle. The coal throughput accounts for as much as $95 \%$ of the total throughput of this port (Table 4). First and foremost, the Port of Newcastle is the world's largest steam coal export port. According to data from the largest operator of the coal export terminal(s) in the port of New- 


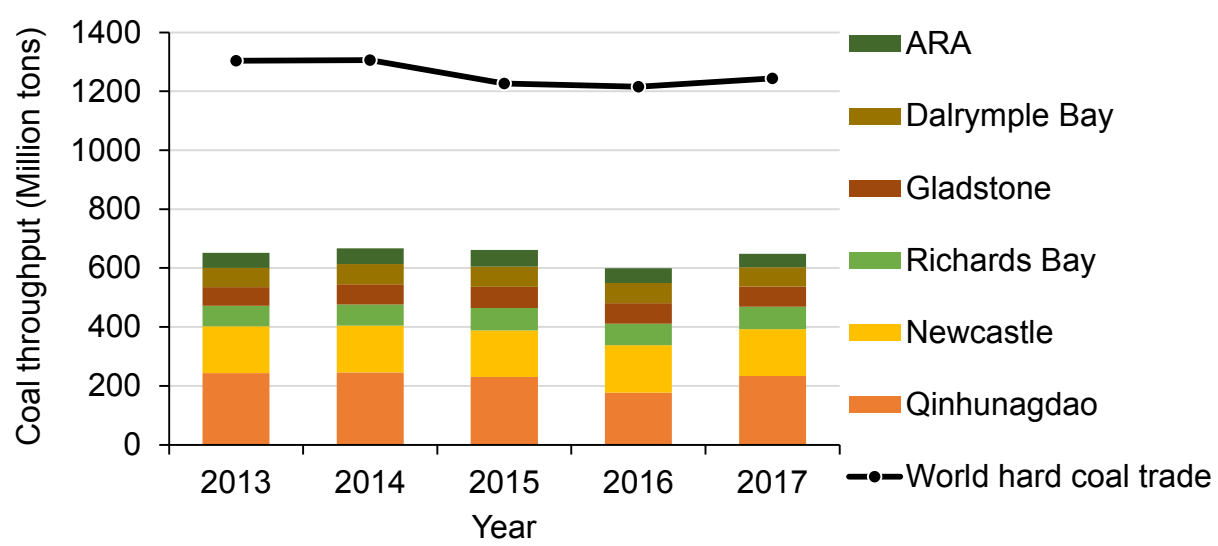

Fig. 7. Coal throughput in the major ports of the world

Source: own work based on (VDKI 2011-2018; UNCTAD/RMT 2011-2017; Qinhuangdao Annual Report 2013-2017; Rotterdam-Port...2011-2017; https://www.portofnewcastle.com.au/; https://rbct.co.za/; https://www.gpcl.com.au; www.dbct.com.au/)

Rys. 7 Przeładunki węgla w głównych portach morskich świata

TABLE 4. The share of coal in the total throughput in the selected seaports

TABELA 4. Porównanie udziału węgla w łącznych przeładunkach wybranych portów morskich

\begin{tabular}{|c|c|c|}
\hline \multirow[t]{2}{*}{ Port } & $\begin{array}{l}\text { The share of coal in the } \\
\text { total throughput in } 2017\end{array}$ & \multirow[t]{2}{*}{ The dominant direction in coal transshipments } \\
\hline & $\%$ & \\
\hline Qinhuangdao & 61 & Domestic and export shipments \\
\hline Newcastle & 95 & Export direction: the dominant share of steam coal exports \\
\hline $\begin{array}{l}\text { Richards Bay Coal } \\
\text { Terminal }\end{array}$ & 100 & Export direction: stem coal export \\
\hline Gladstone & 57 & $\begin{array}{l}\text { Export direction: the dominant share of metallurgical coal } \\
\text { exports (around } 70 \% \text { ) }\end{array}$ \\
\hline $\begin{array}{l}\text { Dalrymple Bay Coal } \\
\text { Terminal }\end{array}$ & 100 & $\begin{array}{l}\text { Export direction: the dominant share of metallurgical coal and } \\
\text { PCI exports (around } 84 \% \text { ) }\end{array}$ \\
\hline \multicolumn{2}{|l|}{ ARA, including: } & \multirow{4}{*}{ Import direction and re-export of coal } \\
\hline Amsterdam & 20 & \\
\hline Rotterdam & 6 & \\
\hline Antwerp & 0,2 & \\
\hline
\end{tabular}

Source: own work.

castle: Port Waratah Coal Services (http://pwcs.com.au/), steam coal accounted for as much as $84-89 \%$ out of 105-112 million tons /year imported in the period 2013-2017. 
The world's second steam coal export port (taking the volume of coal exports into account) is the South African port of Richards Bay. According to Richards Bay Coal Terminal (https://rbct. co.za/) for 2013-2017 coal exports varied from 70 to 76 million tons/year.

From the point of view of Western Europe, Amsterdam-Rotterdam-Antwerp (ARA) ports make up the most important coal hub in Western Europe. The coal is re-exported to European recipients of this raw material from the mentioned ARA ports. When it comes to the coal throughput of these three ports, the two Dutch ports, Rotterdam and Amsterdam, with an annual coal throughput of 25-30 and 20-24 million tons in the years 2013-2017, respectively (based on the data from Rotterdam-Port...2011-2017), are of the special importance.

\section{Freight rates and the world bulk carrier fleet}

Currently, the global trade volume of coal in international markets ranges from 1.1 to 1.2 billion tons. As much as $90 \%$ of coal trade takes place by sea, the rest is land trade between neighboring countries (e.g. US - Canada, Russia - Kazakhstan, Poland - EU countries, CIS countries) or over short distances, where railway or road transport is economically justified or no other options are available (Lorenz et al. 2013 Lorenz and Ozga-Blaschke 2013, Ozga-Blaschke 2017, Grudziński 2017). The most important coal trading markets in the world are Atlantic and Pacific markets. In total, they account for approximately $80-85 \%$ of the total trade volume of this raw material.

Transportation costs affect the final price of coal. In international trade these are primarily the freight costs. Figures 8 and 9 present the freight costs (average annual prices) in coal supplies to consumers in the Atlantic and Pacific region. These rates apply to the most important coal transportation routes. The data in both graphs is compared with the BDI index (Baltic Dry Index). The BDI index is created by the London Baltic Exchange and is a composite of 3 sub-indices: Baltic Capesize, Baltic Panamax, and Baltic Supramax. The BDI includes three component ships: Capesize $-40 \%$, Panamax $-30 \%$, and Supramax $-30 \%$ (since January 1, 2018). The index no longer includes numbers from Handysize vessels.

The index was first published in 1985 at 1000 points. The Baltic Dry Index takes freight costs on 20 different shipping routes into account. Capesize carriers are the largest ships with a capacity greater than 150,000 DWT, Panamax refers to ships with a capacity of $65,000-80,000$ DWT, while Supramax covers carriers with a capacity of 50,000-60,000 DWT.

The presented changes in freight costs are consistent in their tendencies. However, the differences between freight prices in particular years do not result only from the distance between the port and the point of destination. The freight rates are also influenced by other factors such as: economic situations in different regions of the world or the transportation capacity at a given time.

Freight prices from Colombia and South Africa to ARA ports are lower by about $42 \%$ compared to 2010; freight prices in the Asian market are lower by $35 \%$. The BDI index has lost $55 \%$ 
since 2010. The index reached a minimum at the beginning of 2016. Since then, it has increased by $85 \%$. During this period, freight prices of coal increased by $70-90 \%$ depending on the route. In 2010-2017, the share of freight costs (Fig. 10) in the CIF price of steam coal (the price of a good delivered at the frontier of the importing country) was at the level of $10-14 \%$.

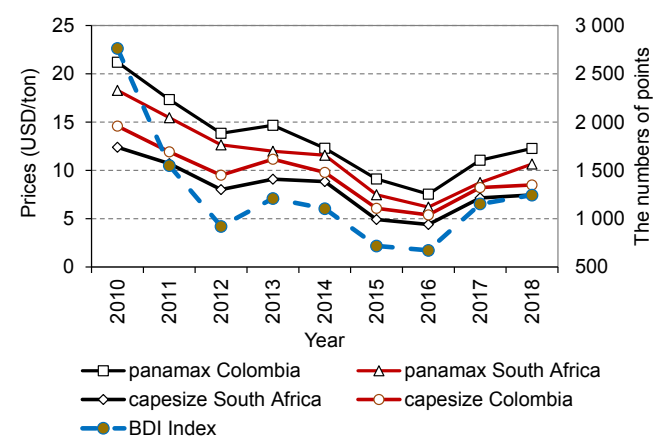

Fig. 8. Freight costs from Colombia and South Africa to the ARA ports

Source: own work based on BDI Lloyd's; Argus; Platts

Rys. 8. Ceny frachtów z Kolumbii i RPA do portów ARA

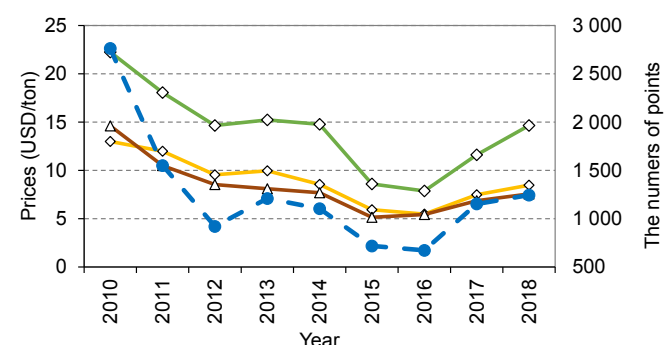

$\diamond$ panamax Australia-Japan $\quad \diamond$ panamax Indonesia-India

$\neg-$ panamax Indonesia-Japan $\rightarrow-B D I$ Index

Fig. 9. Freight costs from Australia and Indonesia to the Asian market

Source: own work based on BDI Lloyd's; Argus; Platts

Rys. 9. Ceny frachtów z Australii i Indonezji na rynek azjatycki

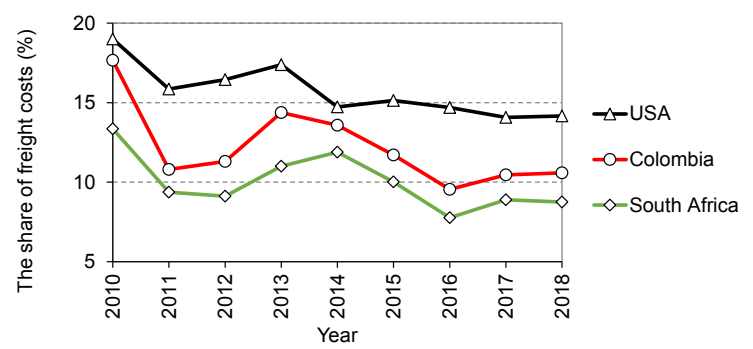

Fig. 10. The share of freight costs (USA, Colombia, South Africa) in the price of steam coal in the ARA ports Source: own work

Rys. 10. Udział kosztów frachtów (USA, Kolumbia, RPA) w cenie węgla energetycznego w portach ARA

Since 2010, a constant increase in the numbers (Fig. 11.a) and tonnage (Fig. 11. b) of the world bulk carrier fleet can be observed. Of the global number of 90 thousand vessels in 2016, 11.6 thousand ships were bulk carriers. In the years 2010-2016, the share of bulk carriers in the world fleet was in the range of $11-15 \%$. In terms of tonnage, bulk carriers accounted for 31-35\% (i.e. 293-439 thousand DWT) of the total tonnage of all types of ships in the world.

The share of new (1-4 years) bulk carriers in the total number of ships on a global scale was $29-46 \%$. The largest share of these new bulk carriers (44-46\%) was recorded in the years 2012-2013. 
a)

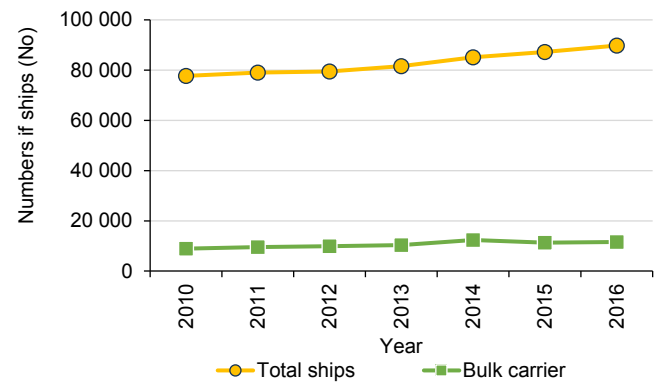

b)

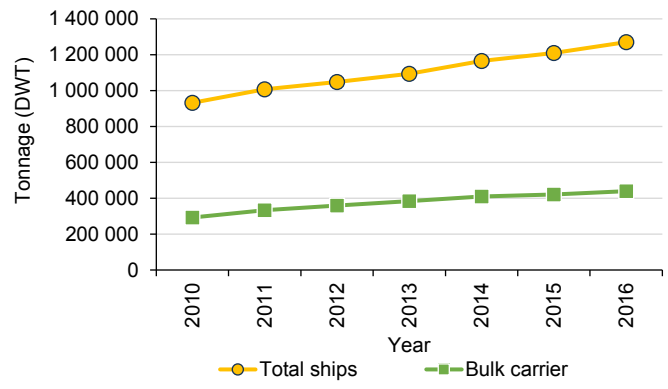

Fig. 11. The numbers a) and the tonnage b) of the world bulk carrier fleet in the years 2010-2016

Source: own work based on Equasis Statistics 2010-2016

Rys. 11. Liczba a) oraz tonaż b) światowej floty masowców, lata 2010-2016

According to analysts from Baltic and International Maritime Council - BIMCO (www. bimco.org), dry bulk shipping will continue to increase as a result of the increasing demand for transportation services. As a consequence, the bulk carrier tonnage will increase, despite the balance between deliveries of new ships and deletions from the fleet in the form of ships scrapped.

\section{Conclusions}

Summarizing these considerations, it can be stated that:

$\downarrow$ The world seaborne trade exceeds 10 billion tons; the share of coal is $10-13 \%$. Oil and gas have a share of around $30 \%$, and $17 \%$, respectively (bulk carriers).

$\downarrow$ Hard coal, which is traded in the international market now accounts for about $15-20 \%$ of the world production of this raw material. As much as $90 \%$ of coal trade takes place by sea; the share of steam coal is $77 \%$.

$\checkmark$ When it comes to the five major bulk commodities (iron ore, coal, grain, bauxite, alumina, and phosphate rock), coal has a share of 36-41\%. In recent years, the share of coal has been on a downward trend and has decreased by $6 \%$ since 2015 .

^ The TOP 20 of the world's largest cargo ports includes 14 Chinese ports, 2 Korean ports, while Singapore, Australia, the US and the Netherlands (the Amsterdam-Rotterdam-Antwerp (ARA)) have one port each.

^ In recent years, e.g. 2010-2017, a huge increase in the total throughput can be observed. With a total cargo throughput of more than 1 billion tons in 2017, i.e. an increase by about 374 million tons in 2010, Ningbo and Zhoushan represent the largest port complex in the world. 
Meanwhile, ports such as: Tangshan (China) and Port Hedland (Australia) increased their coal throughput more than twice.

$\checkmark$ The world's largest coal ports in terms of throughput are: Newcastle in Australia, Richards Bay in South Africa, and Qinhuangdao in China. The most important coal hub in Europe, with the annual coal throughput of 20-24 million tons, is made up of Amsterdam-Rotterdam-Antwerp (ARA) ports.

४ The largest exporters of coal (in descending order) are: Australia, Indonesia, Russia, Colombia, South Africa, and the US. These six countries have an $85 \%$ share in global coal exports. The largest importers are mainly Asian countries: China, India, Japan, South Korea, and Taiwan. The share of these countries in global imports is $64 \%$. The largest importer of coal in Europe is Germany, which imported 54 million tons in 2016.

४ Transportation costs affect the finale price of coal. In international trade these are primarily the freight costs. In recent years, the share of freight costs in the CIF prices was on average $10-14 \%$.

$\checkmark$ In the years 2010-2016, the world bulk carrier fleet ranged from 8.9 to 12.4 thousand vessels, constituting $11-15 \%$ of the total number of ships in the world.

This work was funded by Statutory Research of the Mineral and Energy Economy Research Institute of the Polish Academy of Sciences.

\section{References}

Argus - Argus Coal Daily International. Argus Media Ltd.

Baltic and International Maritime Council - BIMCO [Online] www.bimco.org [Accessed: 2018-07-02].

BDI Lloyd (https://www.quandl.com/data/LLOYDS/BDI-Baltic-Dry-Index).

Coal Information 2017-2016 data. IEA, Paris 2017.

Dalrymple Bay Coal Terminal [Online] https://www.dbct.com.au/) [Accessed: 2018-07-02].

Equasis Statistics 2010-2016 - Equasis Statistics - The world fleet. Issues from the years 2010-2016 [Online] http://www.emsa.europa.eu/equasis-statistics/items.html?cid=95\&id=472 [Accesse: 2018-07-02].

Global ports... 2018 - Global Ports Enjoying a Production Recovery in 2017. Date: 2018-04-18. Shanghai International Shipping Institute [Online] http://en.sisi-smu.org/index.php?c=article\&id=16974 [Accessed: 2018-07-15].

GRUDZIŃSKI, Z. 2017. International steam coal market (Międzynarodowy rynek węgla energetycznego). The Bulletin of the Mineral and Energy Economy Research Institute of the Polish Academy of Sciences No. 98. Publishing House of the MEERI PAS, Kraków, pp. 51-63 (in Polish).

LORENZ et al. 2013 - LORENZ, U., OZGA-BLASCHKE U., STALA-SZLUGAJ K. and GRUDZIŃSKI, Z. 2013. Hard coal in the world and in Poland in the years 2005-2012 (Wegiel kamienny w kraju i na świecie w latach 2005-2012). Studia, Rozprawy, Monografie No. 183. The Publishing House of the Mineral and Energy Economy Research Institute of the Polish Academy of Sciences, Kraków, pp. 184 (in Polish).

LORENZ, U. and OZGA-BLASCHKE, U. 2016. The influence of changing market conditions on forecast prices of coal in international trade (Wplyw zmieniajacych się warunków rynkowych na prognozowane ceny węgla kamiennego w handlu międzynarodowym). Przegląd Górniczy No. 5, ZG SITG Katowice, pp. 3-12 (in Polish). 
OzGA-BlaschKe, U. 2017. Evolution of price mechanism on the international market of metallurgical coal (Ewolucja mechanizmu cenowego na międzynarodowym rynku węgli metalurgicznych). Zeszyty Naukowe Instytutu Gospodarki Surowcami Mineralnymi i Energia PAN No. 98. The Publishing House of the Mineral and Energy Economy Research Institute of the Polish Academy of Sciences, Kraków, pp. 65-75 (in Polish).

Platts - CTI - Coal Trader International. Platts - S\&P Global.

The Port of Gladstone [Online] https://www.gpcl.com.au [Accessed: 2018-07-15].

The Port of Newcastle [Online] https://www.portofnewcastle.com.au/ [Accessed: 2018-07-15].

The Port of Rotterdam Authority [Online] www.portofrotterdam.com [Accessed: 2018-07-15].

Port Waratah Coal Services [Online] http://pwcs.com.au/ [Accessed: 2018-07-15].

Quinhuangdao Annual Report 2013-2017. Annual reports for the years 2013-2017 [Online] http://www. portqhd.com [Accessed: 2018-07-15].

Richards Bay Coal Terminal [Online] https://rbct.co.za/ [Accessed: 2018-07-15].

Rotterdam Port... (2011-2017) - Port of Rotterdam statistics for the years 2011-2017 [Online] www.portofrotterdam.com [Accessed: 2018-07-15].

UNCTAD/RMT 2017 - Review of maritime transport 2016. United Nations Conference of Trade and Development. United Nations Publications, pp. 130.

VDKI (2011-2018) - Jahresberiht. Issues from the years 2011-2018. Verein der Kohleimporteure e.V. [Online] www.verein-kohlenimporteur.de [Accessed: 2018-07-15].

\section{Węgiel kamienny a międzynarodowy handel morski}

\section{Streszczenie}

Międzynarodowy rynek węgla kamiennego stanowi fragment jego światowej produkcji (15-19\% w latach 2010-2017, tj. 1,0-1,3 mld ton/rok). Główna część międzynarodowych obrotów węgla realizowana jest drogą morską stanowiąc $91-94 \%$ ogólnych obrotów handlowych tym surowcem. W artykule skupiono się na omówieniu udziału węgla w światowych morskich przewozach ładunkowych, jak również głównych węglowych portów morskich. Węgiel stanowi jeden z pięciu głównych ładunków masowych suchych wyszczególnianych w statystykach morskich (obok rudy żelaza, zbóż, boksytów i aluminium oraz fosforytów). W latach 2010-2016 udział węgla w strukturze morskich przewozów ładunków w skali globalnej wynosił 36-41\%, a w strukturze pięciu głównych ładunków suchych - 11-12\%. Z analizy przeładunków węgla w różnych morskich portach świata wynika, że pod względem tonażowym największe przeładunki realizowane są w portach: Qinhuangdao (Chiny), Newcastle (Australia) i Richards Bay (RPA). W latach 2013-2017 przeładunki te rocznie wynosiły w sumie 411-476 mln ton węgla. Największymi eksporterami węgla na świecie są państwa: Australia, Indonezja, Rosja, Kolumbia, RPA i USA (łącznie 85\% udziału w globalnym eksporcie węgla), a największymi importerami są głównie kraje azjatyckie: Chiny, Indie, Japonia, Korea Płd. i Tajwan (64\% udziału w światowym imporcie). W przypadku Europy największym im- 
porterem węgla są Niemcy (w $2016 \mathrm{r}$. importowały $54 \mathrm{mln}$ ton). W artykule omówiono także koszty frachtu morskiego oraz flotę masowców. Biorąc pod uwagę cenę węgla u odbiorcy (czyli w porcie importera), udział kosztów frachtów w cenie węgla u odbiorcy w ostatnich latach kształtował się średnio na poziomie 10-14\%. W latach 2010-2016 udział masowców w światowej flocie zawierał się w przedziale 11-15\%, a pod względem tonażowym masowce stanowiły 31-35\% (łącznego tonażu wszystkich rodzajów statków na świecie). Udział masowców najmłodszych (1-4-letnich) w ogólnej liczbie statków w skali globalnej w latach 2010-2016 wynosił 29-46\%.

SŁOWA KLUCZOWE: węgiel kamienny, handel morski, porty morskie, przeładunki, koszty frachtu 
